\title{
USE OF IODINE AND SELENIUM ENRICHED FODDER RATIONS FOR PRODUCTION OF FORTIFIED YOUNG LAMB
}

\author{
Tatyana M. Giro*, Alexey V. Molchanov, Anton N. Kozin, Anna V. Giro, Evgenii V. Fat'yanov, Vladislav V. Svetlov \\ Saratov State Vavilov's Agrarian University, Saratov, Russia
}

Keywords: young sheep, lamb, feed additives, essential trace elements, iodine deficiency, healthy nutrition

\begin{abstract}
The article is devoted to preventive measures to eliminate the problem of dysmicroelementosis in order to increase the productivity of young sheep. The article presents the results of studies of the influence of feeding rations on the growth and development of young sheep of the Edilbaev breed, on the level of their meat productivity and the qualitative characteristics of biologically fortified lamb. Feed additives based on Yoddar-Zn and DAFS-25 were added to the main ration of lambs at the age of four months, once a day, being added into a fodder mixture with concentrates. For the experiment the herd of lambs was divided to four groups of 25 heads each.The changes in live weight at the age of four, five, six and seven months were analyzed, and it was found that at the age of seven months, the absolute average weight gain in the experimental groups varied from $3.45 \mathrm{~kg}$ to $4.49 \mathrm{~kg}$, in the control group it was $3.1 \mathrm{~kg}$, while the largest live weight gain was recorded in group III which received both feed additives based on Yoddar-Zn and DAFS-25. There were no significant differences in the parameters of body measurements, with the exception of group III, where the chest circumference increased by $7.2 \%$, and the height of a lamb at the withers increased in average by $8.1 \%$. It was found that group III had the highest meat density coefficient, equal to 3.9, and the cross-sectional area of m. Longissimus dorsi was equal to $13.61 \mathrm{~cm} 2$. It was noted that the amount of free amino acids of the lamb group III is $18.8 \%$ higher than the meat of the control group. The lamb obtained from the animals of the experimental groups showed a higher protein content and less fat. The ratio of water to protein in all samples was slightly higher than 3.7, which corresponds to the Federa number for meat raw materials. Enriching the rations of the Edilbaevskoy sheep with feed additives Yoddar-Zn and DAFS-25 promotes the stimulation of growth and development of animals, increases the productivity and nutritional value of lamb.
\end{abstract}

\section{Funding:}

The study was performed with a grant from the Russian Science Foundation 19-76-10013 the «Development and introduction of technologies of production and storage of environmentally friendly lamb, enriched with essential micronutrients».

\section{Introduction}

Among the other tasks defined in the strategy "The Fundamentals of State policy in the sphere of healthy nutrition of the Russian Federation population for the period up to $2025^{\prime \prime}$ the most important issues are the support of domestic production of specialized products for healthy nutrition, the development of animals raising technology and the arrangement of specialized zones for organic animal husbandry.

One of the urgent tasks of the agro-industrial complex is the development of progressive methods to obtain the raw meat from organic livestock with certain functional characteristics and composition, which livestock is cultivated through its lifetime to achieve certain quality properties [1].

Breakthrough in technologies of production and processing of agricultural products in Russia has led to production of very numerous and various products of animal origin, often not conforming to criteria of "Healthy food". The reasons for uprising of products like that most often is found in the technologies of raising of the farm animals,

\footnotetext{
${ }^{1}$ Basic State Policy of the Russian Federation in the sphere of healthy nutrition for the period up to 2020. Retrieved from https://rg.ru/2010/11/03/ pravila-dok.html. Accessed January 11, 2021. (In Russian)
}

which allow to obtain high productivity performance due to the use of antibacterial stimulants [2,3].

Reducing the time of fattening, increasing the productivity rate of animals without introduction of hormones, antibiotics, and anabolic drugs, as well as the production of environmentally safe meat raw materials with high sensory and functional and technological properties, is a main priority now $[4,5]$. It's not possible to solve these problems without creating a solid feed base through the development of balanced feed rations for complex of basic nutrients and mineral additives to replenish the missing macro-and microelements. Accordingly, the transition of the meat processing industry to domestic raw materials in the near future is impossible without improving the feed base for animals.

High-quality meat raw materials can only be produced with the help of full-fledged feeding of farm animals in compliance with the due conditions of their farm raising, which make it possible to get the necessary properties without adding feed antibiotics, medicinal, chemical and similar growth stimulants [6].

The problem of feed quality is a problem of global importance, and we need to consider this issue in wider way, thus building a chain: feed-meat-man, which will ultimate- 
ly help solve the problem of human health and the nation as a whole [1].

In modern animal husbandry the use of feed additives in rations of animals that contribute to increasing the productivity of animals and improving the quality of the obtained products has the particular importance. It is especially important to replenish the deficit of macro-and micronutrients in the body of animals. At the same time it is necessary to take into account the properties of each introduced component and the rates of their introduction in order to obtain edible products with a balanced chemical composition and high biological value [7].

The problem of lack or shortage of essential elements in the ration of the Russian population is one of the most important. The lack of such vital microelements as selenium and iodine in the soil and water, and, consequently, in animal products, is found everywhere in the territory of the Russian Federation [8].

Coupled with the already known successful approaches to enriching pork and poultry meat with organic forms of iodine and selenium, the technology of enriching the ration of ruminants, such as lamb, is a new direction and is of scientific and practical interest.

One of the ways to obtain high-quality lamb, which provides a consumer with the necessary trace elements, is the lifetime optimization of the chemical composition of meat by correcting the animals' rations by enriching them with essential nutrients [9]. The use of a protein-carbohydrate complex with an organic form of iodine and selenium increases the digestibility of feed, stimulates the growth and development of animals, increases non-specific immunity. Those factor all together lead to high productivity and to improved quality of the obtained meat raw materials $[10,11]$.

The main advantage of the lifetime enrichment of lamb with the essential elements is elimination of risk of a negative impact (i. e. overdose), because the introduction of the feed supplement is already "approved" by the animals. This way it is possible to eliminate the obligatory control over the content of trace elements in the finished product, while observing the prescription and technological parameters. Fortification or lifetime formation of the properties of raw materials, and then the finished product, is a significant tool to design functional and specialized nutrition, especially given the current trend towards the personification of nutrition [1,12].

In this regard, the efficient direction of the lifetime formation of the quality and technological properties of raw materials, its biological full-value adequacy by optimizing the technology of animal fattening and comprehensive studies of lamb quality with new predicted consumer and functional properties, for prevention of dysmicroelementosis, are of particular relevance and practical significance now.

In order to determine the most efficient feeding rations on the basis of the Educational and Production Enterprise
"Experimental Animal Husbandry" of the Saratov State Agrarian University named after N. I. Vavilov), scientific and economic experiments were conducted, and a comprehensive assessment was given of the lifetime changes in young sheep herd of Edilbaevskaya breed raised on rations enriched with feed additives based on "Yoddar-Zn" and "DAFS-25", vegetable silicon and protein-carbohydrate complex.

Studies to determine the efficiency of enriched rations introduction were carried out on the population of young sheep of a relatively new breed (Edilbaevskaya) for the Russian Federation, which breed features some certain peculiarities in metabolism of these animals.

Edilbaevsky sheep belong to the meat and fat type, these sheep are characterized by incredible meat productivity, capable for big yield of high-quality low-calorie meat used in rationary nutrition, and have a tough coat.

The features of the metabolism of Edilbaevskiy sheep are primarily the following: these sheep are able to digest the feed of the coarsest composition, and conversion of feed is aimed primarily at the formation of muscle mass in animals, which allows them to increase quickly weight gains and accumulate trace elements more efficiently. Iodine, bound by a chemical covalent bond (by amino acid residues - tyrosine), is easily transformed into organically digestible form and absorbed by the internal secretions (thyroid system) of these animals. Unlike the Edilbaevskiy breed, in fine-wooled sheep of the woolly type the feed conversion is primarily aimed at the formation of the wool cover, so these animals are more sensitive to the lack of mineral substances, which makes it difficult to obtain reliable results.

The peculiarities of the Edilbaevskiy sheep metabolism allowed us to reliably identify the form of organic iodine, to control its amount in the form of iodotyrosins, which allows us to deepen and expand the fundamental principles of the lifetime enrichment of raw materials with organic iodine.

The aim of the scientific work was to study the features of impact of rations, enriched with feed additives based on "Yoddar-Zn" and "DAFS-25", for raising of young sheep on stimulation of sheep growth and development, as well as on level of meat yield and quality properties of biologically fortified lamb.

The research objectives were:

- to develop a biologically safe and efficient method of enrichment of lamb in vivo with trace elements using feed additives based on "Yoddar-Zn" and "DAFS-25" introduced to sheep rations;

- to conduct a comprehensive assessment of impact of enriching the sheep rations with additives, including organic forms of iodine and selenium, on sheep growth and development, meat productivity: live weight and slaughter weight of animals, slaughter yield of carcasses, physical and chemical, biochemical, functional and technological, sensory properties of lamb. 
The priority of production of lamb enriched with essential trace elements will provide producers with nonexpensive raw materials for functional products, and, as a result, will contribute to increasing the profitability of the industry, which is a determining factor in solving the problem of food and raw materials safety.

Reducing the time of small cattle fattening, increasing the intensity of weight gain without hormones, antibiotics and anabolic drugs, obtaining lamb with high sensory and functional-technological properties is a priority and an urgent task.

\section{Materials and methods}

In order to increase the productivity of young sheep of Edilbaevsky breed and as the preventive measures to eliminate the problem of iodine and selenium deficiency, the scientists of the Volga Research Institute for the Production and Processing of Meat and Dairy Products and the Saratov State Agrarian University named after N. I. Vavilov developed feed additives based on "Yoddar-Zn" and "DAFS-25", which contain essential trace elements, additionally enriched with a protein-carbohydrate complex and mineral supplement "Coretron". Feed additives were added in addition to the main ration once a day according to the instructions for use. All animals received a general farm ration (FR), the animals of the experimental group in addition to the FR received the proposed feed additive in the amount of $1 \%$.

In order to determine the most efficient rations, the authors carried out scientific and economic experiment. The experiment was carried out at the Educational and Production Enterprise "Experimental Animal Husbandry" of the Krasnokut branch of the Saratov State Agrarian University named after N. I. Vavilov. For this purpose, during weaning of young lambs at the age of four months from their mothers, we formed four groups of young rams of Edilbaevsky breed using the method of pairsanalogues, each group of 25 heads. Feed additives were added in addition to the main ration, according to the instructions for use, once a day in a fodder mixture with concentrates. The dosage of "Yoddar- $\mathrm{Zn}$ " is $100 \mathrm{~g}$ per 1 ton of concentrated feed, 'DAFS-25" - at the rate of 1.6 mg per $1 \mathrm{~kg}$ of feed as part of premixes. The control group received the general farm ration and compound feed only as addition, in amount of 250-300 grams per head per day (FR); I experimental group - compound feed + feed additive "Yoddar-Zn"; II experimental group - compound feed + selenium organic additive "DAFS-25"; III experimental group - compound feed + "Yoddar-Zn" + "DAFS-25".

Feed additives based on "Yoddar-Zn" and "DAFS-25" contain in their composition the supplement "Coretron" and a protein-carbohydrate component - cold-pressed pumpkin cake, in the following ratio $(\mathrm{kg} / 100 \mathrm{~kg}$ of additives), are sources of trace elements and minerals (iodine, selenium, silicon) in organic form:
"Yoddar-Zn"
0.01
"DAFS-25"
0.0002
"Coretron"
0.5
Cold-pressed pumpkin cake
99.49

"Yoddar-Zn" is a source of the most bioavailable iodine in organic form and zinc. It contains iodized milk proteins in combination with zinc compounds with amino acids.

The biological properties of "Yoddar-Zn" are attributable to the presence of bound iodine in this additive, which is necessary for the biosynthesis of thyroid hormones (thyrotoxin, triiodothyropine), which play an important role in metabolism, promote enzyme formation and support the body's protective reactions. In case of simultaneous intake of iodine and organic zinc, which is a co-factor of superoxide dismutase enzymes, no increase of level of superoxide radicals is observed, which improves the biosynthesis of thyroid hormones.

"DAFS-25" is an organic substance - diacetophenonyl selenide with a mass fraction of selenium of at least $25 \%$. Being a component of the animals and poultry ration, it normalizes the activity of the immune system, provides antioxidant and detoxifying effect on the living body, eliminates the possibility of white muscle disease and fatty liver hepatosis. "DAFS-25" is used to increase the immune resistance of young farm animals and poultry to pathogens of various infectious diseases.

Selenium is used to normalize the metabolism, to increase the overall immune resistance of body and the productivity performance of animals.

The additive has the similar effect on the animal's body like vitamin E. It participates in the processes of tissue respiration and oxidative phosphorylation, acts as a inhibitor of certain enzyme systems, has antitoxic properties, and also prevents the over-oxidation of fatty acids and the accumulation of toxic substances in the body, which normalizes metabolism.

The supplement "Coretron" is a gray powder which consists of amorphous earth silicon of biogenic origin. It is a mineral supplement used in the production of compound feeds and premixes for various types of farm animals and poultry, which acts as an anti-tracking agent, an adsorbent of mycotoxins, is a source of water-soluble silicon (organic form), necessary for the stable functioning of the smooth muscles of animals and poultry gastrointestinal tract, as well as improving the absorption of calcium. In addition, its positive effect on reduction of quantity of helminth infestations due to the saturation of the body with amorphous silicon was observed in case of systematical use.

Cold-pressed pumpkin cake contains (\%): crude protein $-22-37$, crude fat -21.15 , crude fiber -11.18 , is a source of essential amino acids (including lysine - up to $3.28 \%$ of the protein level), macro- and microelements (selenium - up to $3 \mathrm{mg} / \mathrm{kg}$ ), is rich in carotenoids and vitamin E. The amino acid cucurbitin, for example, has a therapeutic and preventive effect in gastrointestinal invasions. 
It is also noted that pumpkin cake contributes to the normalization of the gastrointestinal tract functioning, due to which there is an improvement in the feed intake by animals, and a subsequent increase in live weight gain.

In scientific and economic experiments the identical methods of rams raising and fattening were used. At the end of the experiment (105 days) when the animals reached the age of seven months, a control slaughter was carried out in traditional way in a slaughterhouse of the Experimental Animal Husbandry Training and Production Enterprise in accordance with the requirements of the Technical Regulations of the Customs Union ${ }^{2}$. Before the slaughtering all animals were subjected to 24-hour starvation exposure.

The efficiency of enriching rations with organic iodineand selenium-containing feed additives on rams raising and development, their meat productivity, and the quality properties of meat were studied. Zootechnical properties of rams were evaluated according to the conventionally accepted methods used to control the parameters of animals raising by certain parameters - the age of reaching the due live weight (days), the absolute increase in live weight gain $(\mathrm{kg})$ and the average daily increase in live weight gain $(\mathrm{g})$.

Rams raising and development were evaluated by weighing and taking basic measurements of the animals' body parts at the beginning (at 4 months of age) and at the end of the experiment (at 7 months of age).

To determine the meat yield capacity, the dynamics of the live weight of the rams and the slaughter qualities were taken into account. The quality of the carcasses was assessed by the morphological composition: the yield of muscle tissue, of fat tissue and of bone, as well as the meat grade composition: the yield of meat cuts of I and II grades of quality.

We used standard methods to examine physicochemical parameters of the mass fraction of water, fat ${ }^{3}$, protein ${ }^{4}$; the content of minerals (ash) was determined by dry mineralization of the samples in a muffle furnace; the energy value was determined by calculation. The content of the amino acid tryptophan was determined by colorimetric method according to development of a color reaction between the products of tryptophan decomposition formed during its treatment with concentrated hydrochloric acid and $\mathrm{n}$-dimethylaminobenzaldehyde in presence of sodium nitrate (sodium saltpeter) ${ }^{5}$, the content of hydroxyproline was determined by method of alkaline hydrolysis from preliminary defatted sample. The mass fraction of hydroxyproline in meat and meat products was determined in accordance with the procedure specified in this docu-

\footnotetext{
${ }^{2}$ TR CU034/2013 Technical Regulations of the Customs Union "On the safety of meat and meat products" Retrieved from http://docs.cntd.ru/document/499050564. Accessed January 15, 2021. (In Russian)

${ }^{3}$ GOST 23042-2015 "Meat and meat products. Methods of fat determination". Moscow: Standartinform, 2019. - 8 p.

${ }^{4}$ GOST 25011-2017 "Meat and meat products. Protein determination methods". Moscow: Standartinform, 2018. - 14 p.

${ }^{5}$ GOST 34132-2017 "Meat and meat products. Determination of amino acids composition of animal protein". Moscow: Standartinform, 2017. - $16 \mathrm{p}$.

${ }^{6}$ GOST 23041-2015 "Meat and meat products. Method for determination of oxyproline”. Moscow: Standartinform, 2019. - 8 p.
}

ment. The parameter of protein quality was determined by calculation method (the ratio of tryptophan content to hydroxyproline content). To determine the mass fraction of water $(\mathrm{W}, \%)$ MX-50 infrared analyzer (A\&D, Japan) was used for thermogravimetric method. Water mass fraction ranged from 0 to $100 \%$, accuracy was equal to $0.02 \%$, standard measurement mode was applied at temperature of $160{ }^{\circ} \mathrm{C}$. Active acidity $(\mathrm{pH})$ was determined by potentiometric method using an HI 213 microprocessor $\mathrm{pH}$ meter (Hanna Instruments, Germany). The $\mathrm{pH}$ measurement ranged from 0 to 14 , the accuracy was $0.02 \mathrm{pH}$ units [13]. The water activity of raw meat was determined by the cryoscopic method on AVK-10 device. The water activity measurement ranged from 0.75 to 1.00 , accuracy was \pm 0.0010 , resolution: 0.0001 , measurement exposure duration varied from 4 to 5 minutes while aw $>0.95$ ) [14]. Water binding capacity (WBC),\% of total water, was determined by pressing the sample on filter paper.

To carry out multisensor studies on a "VOCmeter" device, three samples were taken from each analyzed lamb sample. For this, the sample under study was crushed and placed into special glass containers (vials). The vials were tightly closed, sealed and thermostated. At the end of the incubation time, a needle was inserted into the vials for automatic sampling of gas subject to analysis, which gas was transferred to the VOCmeter. The analysis of the received responses of metal oxide sensors (MOS1-4) of an "electronic nose" of the device was run with the help of special software "Argus". Sensors specification:

- aldehydes (M1),

- ketones (M4),

- free amino acids (M3),

- low molecular weight nitrogen-containing compounds

According to the results of calculating the arithmetic mean and standard deviation for this sample, the standard error of the arithmetic mean and the boundaries of its confidence interval was determined taking into account the Student's coefficient $t(n, p)$ at a significance level of $95 \%$ $(p=0.05)$ and the number of measurements. Significance of differences between the mean values in the empirical and control experiments was assessed by the $p$-value in case of two-sample unpaired $t$-test with unequal dispersions. Differences were considered significant and trusted when the inequality $P \geq 0.05$ was achieved. In addition in these cases the adherence of inequality $t, t(n, p)$ was checked up, at

where

$$
n=(d f+1) \text {, }
$$

$d f$ is the number of degrees of freedom),

$p=0.05$,

where

where

$$
t=\frac{\left|x_{1}-x_{2}\right|}{\left(s_{1}^{2}+s_{2}^{2}\right)^{1 / 2}},
$$

$x_{1}$ and $x_{2}-$ arithmetic mean values,

$s_{1}$ and $s_{2}$ are their standard errors for two samples of experimental data [15]. 


\section{Results and discussion}

Studies of the effect of feed additives based on Yoddar$\mathrm{Zn}$ and DAFS-25, as well as their combined use on development and meat yield performance of Edilbaevskiy sheep breed showed that the animals of the experimental groups significantly exceeded the values of the control group.

So, when setting up for an experiment at the age of 4 months, the live weight of rams in the control and experimental groups was approximately the same and amounted to $31.16 \pm 0.22 \mathrm{~kg}$ in the control group and $31.27 \pm 0.19 \mathrm{~kg}$ (group I), $31.46 \pm 0.17 \mathrm{~kg}$ (group II) and $31.68 \pm 0.21 \mathrm{~kg}$ (group III), respectively. At the end of the experiment at the age of 7 months the animals had the following average weight: in the control group $-40.47 \pm 0.31 \mathrm{~kg}$, in the Ist experimental group $-41.63 \pm 0.35 \mathrm{~kg}$, the $2^{\text {nd }}$ one $-41.63 \pm 0,35 \mathrm{~kg}$, the IIIrd $-45.21 \pm 0.37 \mathrm{~kg}$. During the experiment there was no mortality of the experimental animals caused by diseases. The data on the dynamics of the live weight gain of the experimental young sheep are shown below in Table 1.

At the end of the experiment, the dynamics of the increase in live weight was observed in the rams of the III $^{\text {rd }}$ experimental group. Those rams received both feed additives (Yoddar- $\mathrm{Zn}+$ DAFS-25) in addition to the main farm ration.

The rams of the Ist group, which received an iodine-containing supplement, exceeded the average live weight over the control group by $2.79 \%(\mathrm{P}>0.95)$, or $1.2 \mathrm{~kg}$.

Animals of the $\mathrm{II}^{\text {nd }}$ group, which received a seleniumcontaining additive, had a greater advantage over the control group, respectively by $7.01 \%(\mathrm{P}>0.95)$, or $3.1 \mathrm{~kg}$. The greatest effect was observed in animals of the III $^{\text {rd }}$ group, which rations were enriched with both additives. Accordingly, the live weight gain advantage over the control group was $10.48 \%(\mathrm{P}>0.95)$ or $4.27 \mathrm{~kg}$.

According to the results of calculating the average daily gain in live weight, the rams of the experimental groups surpass their peers in the control group in the age period 120-210 days of age: in the 1st group by $11.70 \mathrm{~g}$, or $10.17 \%(\mathrm{P} \geq 0.999)$; in the second - by $30.4 \mathrm{~g}$, or $22.74 \%$ $(\mathrm{P} \geq 0.999)$; in the third - by $46.40 \mathrm{~g}$, or $31.0 \%(\mathrm{P} \geq 0.999)$, respectively.

The calculation of the absolute weight gains in the live weight of the rams showed that the animals of the experimental groups showed higher body weight gain in comparison with the animals of the control group within the age period 120-210 days: in I group by $0.35 \mathrm{~kg}$, or $10.14 \%$ $(\mathrm{P} \geq 0.999)$; in II group - by $0.91 \mathrm{~kg}$, or $22.69 \%(\mathrm{P} \geq 0.999)$; in III group - by $1.39 \mathrm{~kg}$, or $30.96 \%(\mathrm{P} \geq 0.999)$, respectively (Table 1).

In terms of live weight dynamics, the animals of the experimental groups surpassed the rams of control group, which, in our opinion, was caused by the enrichment of the rations with additives including organic forms of selenium and iodine.

The parameters of the main measurements of the ram body points are presented below in Table 2. According to them, no significant differences were found between the animals of the experimental groups, with the exception of the animals of the third group, which parameters exceeded the control group: in chest circumference - by $6.9 \mathrm{~cm}$ ( $P>0.95)$, which amounted to $7.2 \%$, in height at withers by $4.3 \mathrm{~cm}(\mathrm{P}>0.99)$, that was respectively $8.1 \%$.

Table 1. Dynamics of live weight gain of Edilbaevskiy rams

\begin{tabular}{|c|c|c|c|c|}
\hline \multirow{2}{*}{ Parameter } & \multicolumn{4}{|c|}{ Groups } \\
\hline & Control group & I & II & II \\
\hline \multicolumn{5}{|c|}{ At birth } \\
\hline Live weight, kg & $3,84 \pm 0,03$ & $3,89 \pm 0.02$ & $3,93 \pm 0,02$ & $3,98 \pm 0,03$ \\
\hline \multicolumn{5}{|c|}{4 months } \\
\hline Live weight, kg & $31,16 \pm 0,22$ & $31,27 \pm 0,19$ & $31,46 \pm 0,17$ & $31,68 \pm 0,21$ \\
\hline Absolute gain, kg & 27,32 & 27,38 & 25,53 & 27,70 \\
\hline Average daily gain, $\mathbf{g}$ & 227,7 & 228,2 & 229,4 & 230,8 \\
\hline \multicolumn{5}{|c|}{5 months } \\
\hline Live weight, kg & $34,26 \pm 0.18$ & $34,72 \pm 0,21$ & $35,48 \pm 0,32$ & $36,19 \pm 0,21$ \\
\hline Absolute gain, kg & 3,1 & 3,45 & 4,02 & 4,51 \\
\hline Average daily gain, $\mathrm{g}$ & 103,3 & 115,0 & 134,0 & 150,3 \\
\hline \multicolumn{5}{|c|}{6 months } \\
\hline Live weight, kg & $37,37 \pm 0,21$ & $38,18 \pm 0,22$ & $39,51 \pm 0,27$ & $40,72 \pm 0,25$ \\
\hline Absolute gain, kg & 3,11 & 3,46 & 4,03 & 4,53 \\
\hline Average daily gain, $\mathrm{g}$ & 103,7 & 115,3 & 134,3 & 151,0 \\
\hline \multicolumn{5}{|c|}{7 months } \\
\hline Live weight, kg & $40,47 \pm 0,31$ & $41,63 \pm 0,35$ & $43,52 \pm 0,29$ & $45,21 \pm 0,37$ \\
\hline Absolute gain, kg & 3,1 & 3,45 & 4,01 & 4,49 \\
\hline Average daily gain, $\mathrm{g}$ & 103,3 & 115,0 & 133,7 & 149,7 \\
\hline
\end{tabular}


Table 3 shows the parameters of meat yield performance of rams, which parameters confirm the trend for achieving the body superiority of animals in the experimental groups over the animals of the control group. The superiority was observed: in terms of pre-slaughter weight, i. e. the Ist group exceeded the control group by $1.2 \mathrm{~kg}, \mathrm{P}>0.95$ (2.9\%), the II ${ }^{\text {nd }}$ group - by $3.1 \mathrm{~kg}, \mathrm{P}>0.95(7.01 \%)$, the III $^{\text {rd }}$ group - by $4.7 \mathrm{~kg}, \mathrm{P}>0.95$ (10.48\%); slaughter yield — by $2.8 \% ; 3.3 \% ; 5.22 \%$ respectively.

Parameters of the slaughter yield and meat qualities, obtained as a result of slaughtering animals, also indicate that introduction of new feed additives to the ra- tion contributed to the body superiority of rams at the age of 7 months in comparison with the experimental group over their counterparts from the control group (Table 3).

For the most comprehensive assessment of the meat yield productivity of rams the morphological composition of the carcasses was also studied. Based on the following parameters such as the mass of boneless meat, fat, bones and tendons, the percentage ratios of these parts to the weight of the carcass were determined.

The morphological composition of carcasses was determined by boning of the individual meat cuts (Table 4).

Table 2. Measurements of body points of Edilbaevskiy breed rams, cm

\begin{tabular}{|c|c|c|c|c|}
\hline \multirow{2}{*}{ Dimensions } & \multicolumn{4}{|c|}{ Groups } \\
\hline & Control group & I & II & III \\
\hline \multicolumn{5}{|c|}{4 months } \\
\hline Height at withers & $53,21 \pm 0,54$ & $53,28 \pm 0,14$ & $53,31 \pm 0,17$ & $53,37 \pm 0,10$ \\
\hline Oblique length of torso & $54,22 \pm 0,18$ & $54,31 \pm 0,17$ & $54,39 \pm 0,11$ & $54,47 \pm 0,14$ \\
\hline Chest girth & $73,12 \pm 0,16$ & $73,22 \pm 0,18$ & $73,23 \pm 0,16$ & $73,42 \pm 0,21$ \\
\hline Chest width & $18,23 \pm 0,21$ & $18,34 \pm 0,23$ & $18,37 \pm 0,25$ & $18,41 \pm 0,23$ \\
\hline Chest depth & $29,31 \pm 0,17$ & $29,33 \pm 0,15$ & $29,35 \pm 0,18$ & $29,39 \pm 0,12$ \\
\hline Rump height & $59,64 \pm 0,12$ & $59,50 \pm 0,14$ & $59,76 \pm 0,13$ & $59,87 \pm 0,18$ \\
\hline Pastern girth & $9,31 \pm 0,18$ & $9,38 \pm 0,18$ & $9,42 \pm 0,19$ & $9,44 \pm 0,16$ \\
\hline Width in hips femurs & $12,26 \pm 0.14$ & $12,28 \pm 0,16$ & $12,31 \pm 0,17$ & $12,32 \pm 0,22$ \\
\hline \multicolumn{5}{|c|}{7 months } \\
\hline Height at withers & $62,22 \pm 0,22$ & $63,74 \pm 0,22$ & $64,26 \pm 0,24$ & $66,47 \pm 0,22$ \\
\hline Oblique torso length & $61,75 \pm 0,14$ & $62,24 \pm 0,13$ & $63,38 \pm 0,16$ & $64,01 \pm 0,14$ \\
\hline Chest girth & $88,67 \pm 0,21$ & $91,36 \pm 0,17$ & $94,29 \pm 0,18$ & $95,65 \pm 0,21$ \\
\hline Chest width & $23,54 \pm 0,22$ & $24,75 \pm 0,22$ & $25,17 \pm 0,20$ & $26,22 \pm 0,16$ \\
\hline Chest depth & $32,33 \pm 0,17$ & $33,19 \pm 0,18$ & $33,77 \pm 0,11$ & $34,28 \pm 0,14$ \\
\hline Rump height & $64,89 \pm 0,13$ & $65,38 \pm 0,12$ & $67,13 \pm 0,18$ & $68,05 \pm 0,16$ \\
\hline Pastern girth & $9,74 \pm 0,18$ & $9,77 \pm 0,17$ & $10,02 \pm 0,13$ & $10,14 \pm 0,15$ \\
\hline Width in hips femurs & $14,18 \pm 0,12$ & $14,35 \pm 0,11$ & $14,57 \pm 0,15$ & $14,72 \pm 0,14$ \\
\hline
\end{tabular}

Table 3. Slaughter parameters of Edilbaevskiy breed rams $(n=5)$

\begin{tabular}{|c|c|c|c|c|}
\hline \multirow{2}{*}{ Parameter } & \multicolumn{4}{|c|}{ Groups } \\
\hline & Control group & I & II & III \\
\hline \multicolumn{5}{|c|}{4 months } \\
\hline Pre-slaughter weight, kg & $31,16 \pm 0,22$ & $31,27 \pm 0,19$ & $31,46 \pm 0,17$ & $31,68 \pm 0,21$ \\
\hline Carcass weight, kg & $11,94 \pm 0,17$ & $11,96 \pm 0,21$ & $12,15 \pm 0,18$ & $12,24 \pm 0,15$ \\
\hline Internal fat mass, kg & $0,61 \pm 0,01$ & $0,63 \pm 0,22$ & $0,64 \pm 0,01$ & $0,67 \pm 0,02$ \\
\hline Fat tail weight, kg & $1,73 \pm 0,18$ & $1,76 \pm 0,14$ & $1,77 \pm 0,12$ & $1,79 \pm 0,15$ \\
\hline Slaughter weight, kg & $14,28 \pm 0,21$ & $14,35 \pm 0,14$ & $14,56 \pm 0,21$ & $14,70 \pm 0,19$ \\
\hline Slaughter yield,\% & 45,83 & 45,89 & 46,28 & 46,40 \\
\hline \multicolumn{5}{|c|}{7 months } \\
\hline Pre-slaughter weight, kg & $40,47 \pm 0,31$ & $41,63 \pm 0,35$ & $43,52 \pm 0,29$ & $45,21 \pm 0,37$ \\
\hline Carcass weight, kg & $16,21 \pm 0,21$ & $17,15 \pm 0,17$ & $18,05 \pm 0,26$ & $19,24 \pm 0,21$ \\
\hline Internal fat mass, kg & $0,78 \pm 0,05$ & $0,82 \pm 0,04$ & $0,85 \pm 0,03$ & $0,97 \pm 0,04$ \\
\hline Fat tail weight, kg & $2,31 \pm 0,23$ & $3,05 \pm 0,27$ & $3,31 \pm 0,18$ & $3,71 \pm 0,15$ \\
\hline Slaughter weight, kg & $19,30 \pm 0,21$ & $21,02 \pm 0,24$ & $22,21 \pm 0,30$ & $23,92 \pm 0,28$ \\
\hline Slaughter yield,\% & 47,69 & 50,49 & 51,03 & 52,91 \\
\hline
\end{tabular}


Table 4. Morphological composition of ram carcasses $(n=5)$

\begin{tabular}{|c|c|c|c|c|}
\hline \multirow{2}{*}{ Parameter } & \multicolumn{4}{|c|}{ Groups } \\
\hline & Control group & I & II & III \\
\hline \multicolumn{5}{|c|}{4 months } \\
\hline Carcass weight, $\mathrm{kg}$ & $11,94 \pm 0,17$ & $11,96 \pm 0,21$ & $12,15 \pm 0,18$ & $12,24 \pm 0,15$ \\
\hline $\begin{array}{l}\text { Content in the carcass: } \\
\text { of boneless meat, kg }\end{array}$ & $9,26 \pm 0,16$ & $9,29 \pm 0,18$ & $9,44 \pm 0,12$ & $9,53 \pm 0,16$ \\
\hline$\%$ & 77,53 & 77,64 & 77,71 & 77,82 \\
\hline of bones, kg & $2,68 \pm 0,11$ & $2,67 \pm 0,14$ & $2,71 \pm 0,13$ & $2,71 \pm 0,11$ \\
\hline$\%$ & 22,47 & 22,36 & 22,29 & 22,18 \\
\hline Meat factor & 3,46 & 3,48 & 3,48 & 3,52 \\
\hline "Muscle eye" area, $\mathrm{cm}^{2}$ & 8,86 & 8,88 & 9,14 & 9,27 \\
\hline \multicolumn{5}{|c|}{7 months } \\
\hline Carcass weight, kg & $16,21 \pm 0,21$ & $17,15 \pm 0,17$ & $18,05 \pm 0,26$ & $19,24 \pm 0,21$ \\
\hline $\begin{array}{l}\text { Content in the carcass: } \\
\text { of boneless meat, } \mathrm{kg}\end{array}$ & $12,69 \pm 0,17$ & $13,46 \pm 0,23$ & $14,28 \pm 0,24$ & $15,31 \pm 0,26$ \\
\hline$\%$ & 78,31 & 78,46 & 79,11 & 79,56 \\
\hline of bones, kg & $3,52 \pm 0,11$ & $3,69 \pm 0,15$ & $3,77 \pm 0,10$ & $3,93 \pm 0,12$ \\
\hline$\%$ & 21,69 & 21,54 & 20,89 & 20,44 \\
\hline Meat factor & 3,61 & 3,65 & 3,79 & 3,90 \\
\hline "Muscle eye" area, $\mathrm{cm}^{2}$ & 12,54 & 12,83 & 13,21 & 13,61 \\
\hline
\end{tabular}

Cutting carcasses in order to determine the morphological composition showed superiority of experimental rams over the control group animals at 7 months of age. The content of boneless meat in the carcasses of the III ${ }^{\mathrm{rd}}$ group was higher than in the control group by $2.62 \mathrm{~kg}$ $(17.0 \%)$. Also, the III $^{\text {rd }}$ group had the highest meat factor -3.90 .

The cross-sectional area of the $m$. longissimus dorsi- the "muscular eye" - was determined on the anterior section of the $m$. longissimus dorsi, along the border between the last thoracic and the first lumbar vertebrae (Table 4). The best parameters of the "muscular eye" also were recorded in carcasses of the III-rd experimental group $-13.61 \mathrm{~cm}^{2}$.

Table 5 below shows the data of physical and chemical parameters of $m$. Longissimus dorsi. This muscle was chosen as parametrical point because of the high variability of the composition and properties of raw meat.
Lamb from animals of the experimental groups slightly differed for the better, this lamb showed a higher protein content and less fat. The water-to-protein ratio in all samples was slightly higher than 3.7 , which corresponds to the Federzahl number for raw meat [16].

The $\mathrm{pH}$ parameter in the control sample is slightly higher than in the experimental ones, and is directly proportional to the parameter of water activity: along with decrease in $\mathrm{pH}$ the activity of water also decreases. The water binding capacity of the samples also decreases with decreasing of $\mathrm{pH}$. The $\mathrm{pH}$ level in all samples was typical for the normal course of the autolysis process.

Table 6 below presents the results of a study of the qualitative protein quotient of lamb muscle tissue based on various feeding rations.

In terms of tryptophan content the meat obtained from animals of the experimental and control groups had no

Table 5. Physical and chemical parameters $m$. Longissimus dorsi obtained from rams of various feeding rations

\section{Parameters}

\section{Water content, $\%$}

Mass fraction of fat, $\%$

Protein mass fraction, $\%$

Mass fraction of ash,\%

pH

Water activity

WBC, \%

Dry matter,\%

"M $\pm \mathrm{m}$ " - mean \pm standard error of the mean

\section{Groups under study}

I

II

III

Control group

$76,99 \pm 0,64$

$77,13 \pm 0,58$

$76,56 \pm 0,96$

$1,62 \pm 0,28$

$1,27 \pm 0,19$

$1,98 \pm 0,29$

$2,62 \pm 0,34$

$16,93 \pm 2,40$

$17,04 \pm 2,35$

$16,98 \pm 0,41$

$1,01 \pm 0,15$

$1,05 \pm 0,06$

$1,08 \pm 0,08$

$1,06 \pm 0,08$

$5,716 \pm 0,013$

$5,635 \pm 0,080$

$\mathbf{5 , 6 1 7} \pm 0,016$

$\mathbf{5 , 5 9 7} \pm 0,007$

$0,9872 \pm 0,0011$

$0,9859 \pm 0,0009$

$0,9850 \pm 0,0010$

$0,9841 \pm 0,0015$

$82,4 \pm 0,5$

$77,8 \pm 0,3$

$77,1 \pm 0,4$

$76,3 \pm 0,3$

20,06

19,60

19,39

20,02 
Table 6. Qualitative protein quotient of lamb muscle tissue based on various feeding rations

\begin{tabular}{|c|c|c|c|c|}
\hline Parameter & Control group & $\begin{array}{l}\text { I group } \\
\text { (Yoddar-Zn) }\end{array}$ & $\begin{array}{l}\text { II group } \\
\text { (DAFS-25) }\end{array}$ & $\begin{array}{c}\text { III group } \\
\text { (Yoddar-Zn+DAFS-25) }\end{array}$ \\
\hline Tryptophan & $0,310 \pm 0,023$ & $0,292 \pm 0,031$ & $0,661 \pm 0,048$ & $0,320 \pm 0,030$ \\
\hline Oxyproline,\% & $0,108 \pm 0,013$ & $0,063 \pm 0,010$ & $0,138 \pm 0,016$ & $0,056 \pm 0,007$ \\
\hline Qualitative protein quotient (QPQ) & 2,87 & 4,64 & 4,79 & 5,69 \\
\hline
\end{tabular}

Table 7. Amino acid composition of ram meat

\begin{tabular}{|c|c|c|c|c|}
\hline \multirow{2}{*}{$\begin{array}{c}\text { Amino } \\
\text { acids }\end{array}$} & \multicolumn{4}{|c|}{ Content of free amino acids ( $\mathrm{g} / 100 \mathrm{~g}$ of product) } \\
\hline & Lamb of control group & $\begin{array}{l}\text { Lamb from the } \\
\text { I group (Yoddar-Zn) }\end{array}$ & $\begin{array}{l}\text { Lamb from the } \\
\text { II group (DAFS-25) }\end{array}$ & $\begin{array}{l}\text { Lamb from the III group } \\
\text { (Yoddar-Zn+DAFS-25) }\end{array}$ \\
\hline Aspartic acid & $1,19 \pm 0,36$ & $1,33 \pm 0,20$ & $1,12 \pm 0,17$ & $1,31 \pm 0,21$ \\
\hline Glutamic acid & $2,42 \pm 0,09$ & $3,51 \pm 0,57$ & $2,52 \pm 0,42$ & $3,71 \pm 0,60$ \\
\hline Serine & $0,58 \pm 0,08$ & $0,62 \pm 0,09$ & $0,50 \pm 0,07$ & $0,65 \pm 0,10$ \\
\hline Histidine & $0,51 \pm 0,10$ & $0,80 \pm 0,12$ & $0,42 \pm 0,06$ & $0,84 \pm 0,13$ \\
\hline Glycine & $0,64 \pm 0,08$ & $0,58 \pm 0,09$ & $0,76 \pm 0,11$ & $0,61 \pm 0,09$ \\
\hline Threonine & $0,54 \pm 0,06$ & $1,12 \pm 0,17$ & $0,49 \pm 0,06$ & $1,18 \pm 0,18$ \\
\hline Arginine & $0,39 \pm 0,11$ & $0,68 \pm 0,10$ & $0,58 \pm 0,09$ & $0,72 \pm 0,11$ \\
\hline Alanine & $0,73 \pm 0,07$ & $0,71 \pm 0,11$ & $0,76 \pm 0,11$ & $0,75 \pm 0,11$ \\
\hline Tyrosine & $0,47 \pm 0,03$ & $0,69 \pm 0,10$ & $0,56 \pm 0,08$ & $0,71 \pm 0,11$ \\
\hline Cystine & $0,18 \pm 0,11$ & $0,22 \pm 0,03$ & $0,16 \pm 0,02$ & $0,25 \pm 0,03$ \\
\hline Valin & $0,73 \pm 0,07$ & $0,74 \pm 0,11$ & $0,75 \pm 0,11$ & $0,78 \pm 0,12$ \\
\hline Methionine & $0,42 \pm 0,09$ & $0,40 \pm 0,06$ & $0,47 \pm 0,04$ & $0,48 \pm 0,06$ \\
\hline Phenylalanine & $0,69 \pm 0,15$ & $0,67 \pm 0,06$ & $0,79 \pm 0,12$ & $0,79 \pm 0,06$ \\
\hline Isoleucine & $0,99 \pm 0,18$ & $1,03 \pm 0,15$ & $0,86 \pm 0,13$ & $1,08 \pm 0,16$ \\
\hline Leucine & $1,18 \pm 0,15$ & $0,98 \pm 0,15$ & $0,95 \pm 0,14$ & $1,03 \pm 0,15$ \\
\hline Lysine & $0,99 \pm 0,07$ & $0,96 \pm 0,14$ & $1,02 \pm 0,15$ & $1,01 \pm 0,15$ \\
\hline Proline & $0,59 \pm 0,36$ & $0,50 \pm 0,08$ & $0,66 \pm 0,10$ & $0,53 \pm 0,08$ \\
\hline Total & $13,30 \pm 2,00$ & $15,54 \pm 2,33$ & $13,37 \pm 2,01$ & $16,37 \pm 2,46$ \\
\hline
\end{tabular}

significant difference. The content of oxyproline was the smallest in lamb of the III ${ }^{\text {rd }}$ group, which contributed to an increase in the qualitative protein quotient from 2.87 in the control group to 5.69 , i. e. by $49.56 \%$.

The results of study of amino acid composition of lamb (Table 7) obtained from the rams of various feeding rations, showed the increase of total amount of free amino acids in lamb of experimental groups.

The lamb from the III ${ }^{\text {rd }}$ experimental group has a higher nutritional value. It showed its superiority in amount of free amino acids by $18.8 \%$ in comparison with meat obtained from the control group.

The content of nonessential amino acids in the protein also was increased, in particular, the greatest increase in content of cystine, arginine, aspartic and glutamic acids was observed [12].

Taking into consideration the fact that the lamb of the III experimental group had a higher nutritional value, the multisensory studies of lamb obtained from animals of this group were carried out in comparison with the control group.

Figure 1 below shows the profile diagrams of the "visual fingerprint" of the samples smell being under study.

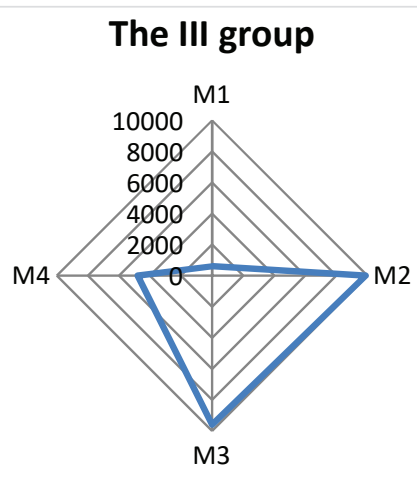

\section{Control group}

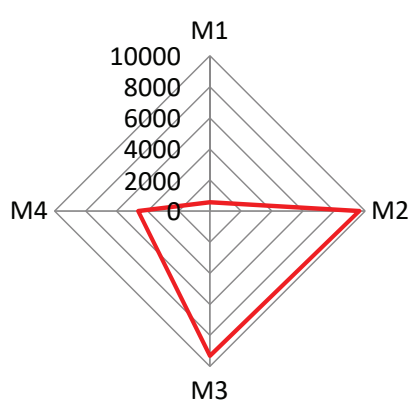

Figure 1. Profile diagrams of the "visual print" of the smell

The Table 8 below shows the "visual prints" of the lamb samples smell.

Table 8. Areas of the "visual prints" of smell

\begin{tabular}{|c|c|}
\hline Sample & $\begin{array}{c}\text { Area of the "visual prints" of smell, } \\
\text { cond. units } \times 10^{7}\end{array}$ \\
\hline Control group & 7,04 \\
\hline III group & 7,49 \\
\hline
\end{tabular}

According to the results of the study, it was found that the intensity of the smell of lamb sample from the III group 
is $0.58 \%$ higher than the lamb sample of the control group, as evidenced by the area of "visual prints" of smell (Table 8). The profiles of "visual prints" of lamb samples from the III and control groups differ in reading of M3 sensor, which showed a slightly higher content of free amino acids in the gas phase of the lamb sample obtained from the III ${ }^{\text {rd }}$ group.

The higher sensory readings of lamb obtained from the III $^{\text {rd }}$ experimental group are explained by the fact that the sum of aroma-forming amino acids (valine, serine, methionine, glutamine, histidine, alanine) in meat of these animals was $25.2 \%$ higher than in the control group (Table 7). Lamb obtained from the III ${ }^{\text {rd }}$ experimental group features a higher content of nitrogenous extractives (methionine) involved in formation of a specific flavor and taste and stimulating the secretory function of the digestive tract, which improves the digestibility of the lamb [17].

\section{Conclusion}

Enriching the diets of Edilbaevskiy breed sheep with feed additives based on "Yoddar-Zn" and "DAFS-25" in combination with a protein-carbohydrate complex stimulates the growth and development of animals, increases the meat yield performance and nutritional value of lamb:

- the dynamics of increase in live weight gain in rams of the experimental groups exceeded the analogous parameters of control group;
- the animals of the III ${ }^{\text {rd }}$ group showed better body parameters in comparison with the control group: in chest circumference - by $6.9 \mathrm{~cm}(\mathrm{P}>0.95)$, which was $7.2 \%$, in height at withers - by $4.3 \mathrm{~cm}(\mathrm{P}>0.99)$, respectively $8.1 \%$; - in terms of meat yield performance of rams the experiment confirmed the tendency of the advantage of animals from the experimental groups over the control group, the superiority in terms of pre-slaughter weight was from $1.2 \mathrm{~kg}$ to $4.7 \mathrm{~kg}$;

- the content of boneless meat in the carcasses of the III ${ }^{\mathrm{rd}}$ group exceeded the same parameters of the control group by $2.62 \mathrm{~kg}(17.0 \%)$;

In terms of content and qualitative quotient of protein and fat, the lamb of the experimental batches outdid the parameters of the control group, which confirms the efficiency of introduction of the rations enriched with essential microelements, the lamb obtained from the animals of the experimental groups also has a higher nutritional value.

The obtained results allow stating that the development and implementation of technologies for formation of meat yield performance of small ruminants, the production of lamb of the predictable composition and quality due to lifetime enrichment of the animal body with essential microelements, is a priority sphere of activity, which solution has scientific and practical importance for implementation of the Food Safety program of the Russian Federation.

\section{REFERENCES}

1. Gorlov, I.F., Mosolov, A.A., Yuldshbaev, Yu.A., Knyazhechenko, O.A., Gishlarkaev, E.I. (2018). Fatty acid composition of fat of rams and steers grown in the conditions of natural pastures of the Trans-Volga region. Sheep, goats, wool business, 2, 38-40. (In Russian)

2. Kulikovskiy, A.V., Lisitsyn, A.B., Kuznetsova, O.A., Vostrikova, N.L., Goriov, I.F. (2016). Method of determination organic iodine (iodotyrosines) in food. Voprosy Pitaniia, 85(4), 91-97. (In Russian)

3. Molchanov, A.V., Egorova, K.A. (2017). Weight growth and parameters of slaughter of Edilbaevsky rams of different types of birth. Sheep, goats, wool business, 4, 21-22. (In Russian)

4. Bo Trabi, E., Seddik, H.-E., Xie, F., Wang, X, Liu, J., Mao, S. (2020). Effect of pelleted high-grain total mixed ration on rumen morphology, epithelium-associated microbiota and gene expression of proinflammatory cytokines and tight junction proteins in Hu sheep. Animal Feed Science and Technology, 263, Article 114453. https://doi.org/10.1016/j.anifeedsci.2020.114453

5. Bo Trabi, E., Seddik, H.-E., Xie, F., Lin, L., Mao, S. (2019). Comparison of the rumen bacterial community, rumen fermentation and growth performance of fattening lambs fed low-grain, pelleted or non-pelleted high grain total mixed ration. Animal Feed Science and Technology. 253, 1-12. https://doi.org/10.1016/j. anifeedsci.2019.05.001

6. Zhang, J., Li, H., Kong, L., Su, J., Ma, J., Feng, B. (2018). Optimization of processing parameters of straw and particles feed for fattening lamb. Nongye Gongcheng Xuebao/Transactions of the Chinese Society of Agricultural Engineering, 34(5), 274-281. https://doi.org/10.11975/j.issn.1002-6819.2018.05.036 7. Traisov, B.B., Smagulov, D.B., Yuldashbaev, Y.A., Esengaliev, K.G. (2017). Meat productivity of crossbred rams after fattening. Journal of Pharmaceutical Sciences and Research, 9(5), 574-577. 8. Kulikovskii, A. V., Lisitsyn, A. B., Chernukha, I. M., Gorlov, I. F., Savchuk, S. A. (2016). Determination of lodotyrosines in Food. Journal of Analytical Chemistry, 71(12), 1215-1219. https://doi. org/10.1134/S1061934816100087
9. Bhatt, R.S., Soni, L., Gadekar, Y.P., Sahoo, A., Sarkar, S., Kumar, D. (2020). Fatty acid profile and nutrient composition of muscle and adipose tissue from Malpura and fat-tailed Dumba sheep. Indian Journal of Animal Sciences, 90(3).

10. Bhatt, R.S., Sahoo, A., Soni, L.K., Gadekar, Y.P. (2017). Effect of Protected Fat as Ca-Soap and Formaldehyde-Treated Full-Fat Soybean in the Finisher Ration of Lambs on Growth Performance, Carcass Traits and Fatty Acid Profile. Agricultural Research, 6(4), 427-435. https://doi.org/10.1007/s40003-017-0273-7

11. Al-Suwaiegh, S.B., Al-Shathri, A.A. (2014). Effect of slaughter age on the fatty acid composition of intramuscular and subcutaneous fat in lamb carcass of Awassi breed. Indian Journal of Animal Research, 48(2), 162-170. https://doi.org/10.5958/j.0976-0555.48.2.035 12. Giro, T.M., Kulikovsky, A.V., Knyazeva, A.S., Domnitsky, I. Yu., Giro, A.V. (2020). Biochemical and microstructural profile of the thyroid gland from lambs raised on experimental rations. Food Processing: Techniques and Technology, 50(4), 670-680. https://doi. org/10.21603/2074-9414-2020-4-670-680 (In Russian)

13. Fatyanov, E.V., Sidorov, S.A. (2018). On the analysis of the overall chemical composition of raw meat. The herald of beef cattle breeding, 3(91),75-78. (In Russian)

14. Fatyanov, E.V., Aleynikov, A.K. (2017). Improving the cryoscopic method determination of water activity in food products. The agrarian scientific journal, 8, 61-65. (In Russian)

15. Johnson, R.A., Bhattacharyya, G.K. (2010). Statistics. Principles and methods, 6th ed. USA: John Wiley \& Sons, Inc. - 706 p. ISBN-13 978-0-470-40927-5

16. Scheuer, R. (2013). From the art of tasting to global standardization. The development of analytical chemistry in Flesch research in Kulmbach. Bulletin of the meat research Kulmbach, 52(201), 141-146. (In German)

17. Giro, T.M., Kulikovskii, A.V., Giro, V.V., Mosolov, A.A. (2020). Microstructural studies of muscle tissue of lamb of aboriginal breeds of the Volga region. IOP Conference Series: Earth and Environmental Science, 548(8), Article 082082. https://doi. org/10.1088/1755-1315/548/8/082082 


\section{AUTHOR INFORMATION}

Tatyana M. Giro - doctor of technical sciences, professor, Department "Technology of production and processing of livestock products", Saratov State Vavilov Agrarian University. 410012, Saratov, Teatralnaya Square, 1. Tel.: +7-960-342-30-16, E-mail: girotm@sgau.ru ORCID: https://orcid.org/0000-0003-3039-1324

* corresponding author

Alexey V. Molchanov - doctor of agricultural sciences, professor, Head of the Department "Technology of production and processing of livestock products", Saratov State Vavilov Agrarian University. 410012, Saratov, Teatralnaya Square, 1. Tel.: +7-927-134-58-02, E-mail: molchanov_av@mail.ru

ORCID: https://orcid.org/0000-0002-0819-1484

Anton N. Kozin - candidate of agricultural sciences, docent, Department "Technology of production and processing of livestock products", Saratov State Vavilov Agrarian University. 410012, Saratov, Teatralnaya Square, 1. Tel.: +7-960-358-06-45, E-mail: a.kozin.90@mail.ru ORCID: https://orcid.org/0000-0001-8674-4382

Anna V. Giro - candidate of biological sciences, docent, Department "'Technology of production and processing of livestock products"', Saratov State Vavilov Agrarian University. 410012, Saratov, Teatralnaya Square, 1. Tel.: +7-937-026-28-22, E-mail: giroannasgau@gmail.com ORCID: https://orcid.org/0000-0001-8659-1566

Evgenii V. Fat'yanov - candidate of technical sciences, docent, Department "Technology of production and processing of livestock products", Saratov State Vavilov Agrarian University. 410012, Saratov, Teatralnaya Square, 1. Tel.: +7-902-040-73-32, E-mail: fatjan@mail.ru https://orcid.org/0000-0002-0527-6036

Vladislav V. Svetlov - candidate of agricultural Sciences, senior laboratory assistant, Department "Technology of production and processing of livestock products”, Saratov State Vavilov Agrarian University. 410012, Saratov, Teatralnaya Square, 1. Tel.: +7-960-344-62-52, E-mail: svsvetlov1992@mail.ru https://orcid.org/0000-0003-0270-1970

All authors bear responsibility for the work and presented data.

All authors made an equal contribution to the work.

The authors were equally involved in writing the manuscript and bear the equal responsibility for plagiarism.

The authors declare no conflict of interest.

Received 29.01.2021 Accepted in revised 01.03.2021 Accepted for publication 25.03.2021 